\title{
Distorted Dialogue in Richard Matheson's I Am Legend: A Bakhtinian Perspective
}

\author{
Hamed Faizi \\ English Department, Faculty of Letters \& Humanities, Razi University, Kermanshah, Iran \\ E-mail: hamed.faizi89@gmail.com \\ Ali Taghizadeh (Corresponding author) \\ English Department, Faculty of Letters \& Humanities, Razi University, Kermanshah, Iran \\ E-mail: altaghee@zedat.fu-berlin.de
}

Doi:10.7575/aiac.alls.v.6n.4p.36

Received: 07/03/2015

URL: http://dx.doi.org/10.7575/aiac.alls.v.6n.4p.36

Accepted: 18/05/2015

\begin{abstract}
Based on the theories of Mikhail Bakhtin, a dialogue can necessarily take place only in a two-sided communication. But if a party creates a hierarchical situation for the domination of its voice in the context, the communication will no longer be dialogic. In I Am Legend, Richard Matheson depicts a post-apocalyptic world that is destroyed due to the spread of a disease which metamorphoses people into bugs. The bacterium of this disease is denotatively and symbolically the aftermath of a war in which every party attempts to suppress the other parties to establish a monologue to its own advantage. But Robert Neville, Matheson's main character, tries to find a cure for this exasperation. As he kills the new creatures, his attempt is a measure to delete the factors which make the "other" intolerable for him. When the new nonhuman race is ultimately at the threshold of creating another society, they look upon him in the same way he used to look upon them. However, the new society finally decides to execute him. A Bakhtinian reading of the novel shows that almost all the position-holders try to erase the dialogue and establish their own authority. It causes disastrous consequences like violent exclusions. The present research takes it to analyze the attempts in the novel which want to destroy dialogue, and to expose the disastrous results of each participant's efforts to exclude the other party. These efforts lead each party, especially the marginalized one, to an alienation where they have to spend their times in violence and frustration.
\end{abstract}

Keywords: I Am Legend, Matheson, Bakhtin, Dialogism, Monologism, Post-apocalypse

\section{Introduction}

In the Bakhtinian dialogic context the voices are independent. Mikhail Bakhtin takes it natural to dialogue that each voice should interact with other voices while it has the right freely to be spoken out in the context. But if the privilege to suppress the other voices is given to a certain voice, the dialogic context will get demolished, and the possibility of what Ball and Freedman call "the development of the whole person" gets exhausted. Ball and Freedman affirm that, "Bakhtin and his followers are interested in the development of the whole person and his or her complex of ideas and concepts,... but not to the exclusion of other parts of the idea system" (2004, p. 5). Out of dialogue, there is nothing to curb the voices. Therefore, it is likely that they turn to become authoritative an aftermath of which is a further development of radicalism which in turn can lead to the decline of democracy. Bakhtin sheds still more light on the risks of this radicalism emerging from the monologic. He says, "in the monologic world... a thought is either affirmed or repudiated; otherwise it simply ceases to be a fully valid thought" (1984, p. 80). In such a background, only the prevailing thought often comes to the fore and imposes itself on the other thoughts while the other thoughts get marginalized and lose their validity. White believes that, "monologism, according to Mikhail Bakhtin, represents the shutting down of dialogue and its alteric potential. For Bakhtin and his followers, monologism exists where ultimate truth claims, as truth-istina, do not make room for alternative perspectives on truth, as truth-pravada" (2008, p. 3). The disarmament of the alternative along with the imposition of fixity proves the monologic not only authoritative but banal and dispirited also.

I am Legend reads about the spread of a deadly disease which puts the human race on the edge of extinction. A last war between humans has grounded the disease to become epidemic. This is the time when dust storms spread the host mosquitos all over the world carrying the bacteria. Thus, the war symbolically depicts the attempts which destroy the dialogic, for each side involved in war tries to vanquish the other side and impose his own voice on him. The disease creates an apocalypse the smash of which shows us a post-apocalyptic world where most of the human civilization is already extinguished. In this narrative space, Robert Neville is perhaps the only human creature who survives while his life is often threatened by the human mutants whom he hunts whenever he has the chance. Causing a war between humans and real vampires, the disease turns most of the humans into vampire-like creatures. On the one hand, Robert tries to discover a cure for the disease. On the other hand, trying to infect humans, the vampires convert them to bugs, 
non-human creatures. At the end, these vampires become smarter and establish their own society. They also execute Neville to guarantee both their own survival and the destruction of the marginalized party.

Critical studies on I am Legend have often focused on three main themes. One is horror, another one is the postapocalypse, and the last one is loneliness. The present study will intend critically to analyze all of them. However, it seems that Matheson's novel has not yet been approached in the light of Bakhtinian theories on dialogism and unfinalizability in fiction. Therefore, the present study will also take to reveal the representation in it of the potential dangers of the exhaustion of dialogism. We will argue that in the exhaustion of dialogism war becomes widespread with destructive consequences. In other words, the present research attempts to critically analyze the efforts both of the humans and the newly born society to wipe each other off the scene of existence. Each of these species in Matheson's novel tries to do so by imposing the logic of his or her own monologue on the other species. Such a conduct leads to the execution of Robert while he is the last hope of a still uninfected human race to find a cure for the disease. Literally speaking, it leads to the extinction of the ordinary human beings. Trying to exclude a participant from the dialogue will ground the establishment of a monologue with disastrous issues that violently excludes that participant.

\section{Discussion and Analysis}

Mikhail Bakhtin's theories have attracted many literary critics since his revival or better to say rising in the west. Bemong and Borghart state that, "Since western scholars became acquainted with his writings in the 1970s and 1980s, the Russian scholar Mikhail Bakhtin has been an indispensable figure in literary theory and a number of related disciplines in the humanities" (2010, p. 3). The notion of dialogue surely plays the most crucial role in the Bakhtinian writing, and it is widely applied to literary studies; "In literary theory, dialogue... signifies the organizing of fictional texts, usually novels, to allow the interplay of different voices, minds or value systems in such a way that none is superior to another" (Vagaan, 2007, p. 90). In a dialogic context, the participants have the privilege to establish their presence through uttering their outlooks and without the fear of being either suppressed or excluded from the dialogic context. This means that any hierarchical organization is a threat to dialogism to which it runs counter. On the other side, the established power, which often tends to be monologic in its conducts and communications, tries to show only a single side of the coin of truth which guarantees its advantages. However, what is more important for Bakhtin is whether a literary text is ideally dialogic. Actually, our dialogues ground the realization of our consciousness, and it is the way our actions take roles in society. Dentith claims that "consciousness can only realize itself, however provisionally, in dialogue with the other" (1995, p. 42). And also White affirms that dialogue is "an ongoing social process of meaning making that occurs between people as subjects" (2008, p. 5). In a dialogic context, man understands his presence not as a taken-for-granted entity but in relation to the presence and participation of another man, even if this another man tries to alienate him by pushing him out of the field. This is to mean that even if there is a hierarchical system working in the field that wants to suppress the other participant, we still can realize the existence of the suppressed participant. From the eye of Bakhtin, as an outcome of negotiation, our being cannot be defined in isolation, because "sharing existence as an event means among other things that we are-we cannot choose not to bein dialogue, not only with other human beings, but also with the natural and cultural configurations we lump together as 'the world"' (Holquist, 2002, p. 28). On the natural level, our dialogue makes us connected with the physical nature, that is, with other natural phenomena like the Earth, the sun, the wind, and the unstoppable sequence of nights and days. On the cultural level, it is the gate of our social being, the meaning of our life in relation to the institutes like family, school, the police, the bank, and the church. But on the human level, which is the most innate to our own selves, it is the guarantee of our understanding about our others or our fellowmen also, the guarantee of our comprehension about the other people who experience the world in more or less the same ways as ourselves. About the interdependence of the self and other in dialogue, Kershner provides more elaborations:

Bakhtin's idea of the self is radically dependent upon others; the self, for him, is an act of grace, the gift of the other. Human consciousness is formed only in a process of perpetual negotiation with other selves by way of their 'languages'. Selfhood is supremely social, and a person who grew up without ever having been exposed to speech would not be fully human for Bakhtin (2001, p. 21).

Therefore, it seems that the monologic is actually far from genuine, because even if a dialogue between two parties inclines to be one-sided, dialogue is in closer terms not only with creation but with consciousness also. Dialogue may happen everywhere, but its genuineness is the condition that all the participants in it have the priority to freely utter their outlooks. Such a genuine dialogue provides us with the possibility of the intersection of heterogeneous horizons to the advantage of critical interpretation. Holquist believes that,

Bakhtin, on the other hand, conceives monologue as not only secondary in importance to dialogue, but as having a different ontological status. Dialogue is real, monologue is not; at worst, monologue is an illusion, as when it is uncritically taken for granted. Or at best, monologue is a logical construct necessary to understand the working of dialogue (2002, p. 57).

Focusing on dialogism, Bakhtin basically takes his attention from who says the truth to give it to the exchange of opinions between participants. Thus, the question "who says the truth?" gives place to the question "who says what?", while no party is privileged to impose his thoughts on the other party. So, one can suggest that by dialogic Bakhtin means an occasion where everybody has the right to freely express his existence, and by so doing he not only infuses his idea with the idea of the other but also for the idea of the other to be infused with his own idea. It is this idea 
interfusion (or idea intertwining) which makes a communication ideally dialogic. On the contrary, by the monologic Bakhtin means the systems with authoritative figures who distort the dialogic by creating hierarchical pyramids of power and discrimination.

Matheson's novel depicts a post-apocalyptic world where mutant humans kill real humans for their survival. Yet, Robert, as the only human survivor, either fights them or tries to find a cure for the virus that has caused the metamorphosis. Thus, the novel is his life story. For five months he passes a lonely life in a post-apocalyptic world while he gets into contact with no other human being. In the third year of his loneliness, we seem him finally executed. In the course of the novel, a number of flashbacks offer data about why this apocalypse should happen and how Robert loses his family. At first, the reader looks upon these vampires as cliché blood-sucking creatures that he often sees in commercial movies. But later he finds out that they are on the verge of establishing a society; and they start to look upon humans in the same way that the reader used to look upon them. Near the end of the story Ruth warns Robert of the impending danger of the vampires: "they're [vampires] terrified of you, Robert, they hate you. And they want your life" (Matheson, 1997, p. 95).

In the whole story, Robert's mode of conduct is monologic, and he constantly fights with the vampires. We see him in two different episodes. In the first one, he has been alone for five months, while in the second he is in the third year of his loneliness. Yet, he still cannot find any man with whom to stand in relation. In the first episode, he is an edgy person who has lost his temper because of loneliness and lack of communication. We see him living a literally solitary life due to which he is getting depressed while his only nourishment is drinking and smoking. It is pretty natural for a person like him to become depressed when he is denied of all forms of social intercourse whose life is typically comprised only of daily routines. There is no dialogue in his life, a kind of life which is therefore almost impossible for a man to pass. Considering the social dimensions of human life, "Bakhtinian theories support the study of social norms and processes, not isolated individuals. Ideology is part of a social process, which can only be understood by analyzing its social and interactive essence" (Ball and Freedman, 2004, p. 29). The first thing that Robert usually does after waking up in the morning is smoking. As usual, he either attends some chores at home or scavenges the city for supplies. And his listening to very much music testifies that his conduct is inclined to the monologic, because when one is listening to the music, his communication is only one-sided. The voices and screams of his vampire neighbors bother him so much that he soundproofs his house so that "they could scream and howl all they wanted and he didn't have to listen to them. He especially liked not having to listen to Ben Cortman [his neighbor and they used to be friends but now Ben is a vampire] any more" (Matheson, 1997, p. 25). This soundproofing symbolizes the fact that he wants to suppress the other party. When we move to the second episode, Robert has already experienced three years of loneliness. He has turned to an antisocial person who has got used to this lonely style of life. He has started to have delusions about having a companion, and even his plans to befriend a dog turn out to be pathetic efforts that finally kill the dog. Monologic features of his life style are realized almost everywhere. Everything in his place smells of a single vegetable, which is the smell of the garlic he uses for protection. Even his nutrition suggests that his life is cold and stale, because everything which he consumes, even fruits and vegetables, is frozen. When he wants to hear a voice he can only listen to the music. Robert's living in this post-apocalyptic situation is summarized into either finding the necessities of life or fighting the creatures.

The absence of dialogue is felt even in the city where Robert is residing. Once, this city was populated by many people. But it is far from unbelievable that they are no longer taking use of the advantages of dialogue. Hence, absence of dialogic communication is the central theme of Matheson's novel. For example, "he [Robert] frowned as he drove along the empty boulevard, the only sound the muted growling of the motor in his car" (1997, p. 11), and as another example, "he [Robert] started the car and backed quickly into the street and headed for Compton Boulevard. There he turned right and headed east. On both sides of him the houses stood silent, and against the curbs cars were parked, empty and dead... . There was no one to be seen anywhere" (Matheson, 1997 p. 10). The mechanical and deadly situation of Matheson's character, which is overwhelmingly silent and empty also, and the fact that there is no one in his thereabouts with whom he can communicate, tell the believable tale of a man who is denuded of the conditions of dialogue. In another example, the text directly points to the absence of dialogue by explaining Robert's idea as to singing birds: "there was no sound but that of his shoes and the now senseless singing of birds. Once I thought they sang because everything was right with the world, Robert Neville thought, I know now I was wrong. They sing because they're feeble-minded" (Matheson, 1997, p. 18). Birds are feeble in mind. They unknowingly create language stuff, but in the stuff they create there is no sense, no communication. So, they are out of dialogue. Robert too is out of dialogue, because however language is affluently at hand, language is actually inaccessible to him. Thus, one can suggest that the birds' feeble-mindedness allegorizes his inability to create dialogue, which is similar to when we see him listening to classical music pushing him out of communication.

In confrontation with the vampires, Robert either tries to kill them or desperately searches for a way to cure them. His attempt to find a cure for the virus is another symbolic way of enhancing the monologic at the expense of the dialogic, because it is clear that he will not accept the presence of a party other than his own. This hostile interaction between humans and vampires is shown on a symbolic level. It is fixed from its commencement, and it remains finalized. Notwithstanding, what usually leads to the inconclusiveness of dialogue is the unfinalizable interactions between participants, because their dialogic interactions transfer them to an "inconclusive context" where "all the semantic stability of the object is lost; its sense and significance are renewed and grow as the context continues to unfold" (Bakhtin, 1981, p. 30). As a result, it is natural for the dialogic to be in an unstoppable process of formation and reformation in which there is no final resolution. 
In Matheson's novel, war on different levels shows that a certain truth has already been defined which implies their finalized mode of thinking. But a basic requirement of dialogue is its open-endedness or unfinalizability. Bakhtin argues that the presence of participants in a dialogue is essentially relative while their relative presence demands it to be perpetuated. Dialogue actively looks to the future, which makes it even more tangible and inconclusive. But in order to establish a monologic system one needs to be finalized; if a party wants to impose its dominance over the other party, firstly they should create hierarchies. This is what happens in Matheson's novel, for each party tries to keep the hostile relationship in practice. For example, Robert changes his direction and resets his goals from killing the vampires and merely surviving the day to conscious efforts to find a cure for the disease; so whatever he does is a way to keep the monologue running because he cannot accept the other (vampire) the way it is. Even vampires mutate and become so intelligent that they create a society; this society also keeps the hostile positions toward the humans or better to say Robert Neville because he is probably the last human being.

The notion of legend plays a crucial role in understanding the distorted dialogue here; by legend Robert refers to superstitions about vampires that have come true in the storyworld. In his point of view, vampire is "something black and of the night had come crawling out of the middle Ages. A tenuous legend passed from century to century" (Matheson, 1994, p. 13). We used to scare ourselves with these legendaries not only for fun but also for thinking about the secrets of life more carefully and inquisitively, but now, as they've come true, they are a real part of our life and consciousness. However, metaphorically they refer to those propagandas which the dominant party uses to warn us about the marginalized party. When they want to deprive somebody of the privilege of their relations, they just coin scary legends about them to damage their reputation and shift the public opinion for their own benefits. Robert considers some American politicians even more dangerous than these creatures when he says:

But are his [vampire] needs any more shocking than the needs of other animals and men? Are his deeds more outrageous than the deeds of the parent who drained the spirit from his child? The vampire may foster quickened heartbeats and levitated hair. But is he worse than the parent who gave to society a neurotic child who became a politician? Is he worse than the manufacturer who set up belated foundations with the money he made by handing bombs and guns to suicidal nationalists? ... All he does is drink blood (Matheson, 1997, p. $15)$.

And he continues to refer to the marginalized position of vampires:

Why, then, this unkind prejudice, this thoughtless bias? Why cannot the vampire live where he chooses? Why must he seek out hiding places where none can find him out? Why do you wish him destroyed? Ah, see, you have turned the poor guileless innocent into a haunted animal. He has no means of support, no measures for proper education, he has not the, voting franchise. No wonder he is compelled to seek out a predatory nocturnal existence (Matheson, 1997, p. 15).

Here, Robert directly refers to the lower and suppressed communities of his society. When vampires come to power a similar process is repeated; Robert turns to a legend, a superstition that scares vampires. Even before his execution, he thinks to himself "I'm the abnormal one now. Normalcy was a majority concept, the standard of many and not the standard of just one man" (Matheson, 1997, p. 95). Robert has already found out that "he did not belong to them; he knew that, like the vampires, he was anathema and black terror to be destroyed" (Matheson, 1997, p. 96). He used to hunt them once and when they become more powerful, they start hunting him down. Now the human has turned to the beast and vampires are (considered) normal creatures. This happens when the hierarchy turns in a circular way; the dominant party becomes marginalized while the marginalized one becomes dominant, and all of this happens because the dialogic is misrepresented.

However, the decadence becomes more tumid when we realize that not only Robert but the vampires also are inclined to the monologic. For instance, there are vampires who wait for a chance to kill Robert. If Robert rules the day, these vampires rule the night, while their opposition ultimately leads to the former's execution by the runners of the new society. Although not all members of the Vampires' counsel agree with Robert's execution, a majority of them demand it. They are afraid of Robert in the same way he used to be afraid of them; even Robert says "a new terror born in death [by new terror Robert actually refers to himself as a human being], a new superstition entering the unassailable fortress of forever. I am legend" (Matheson, 1997, p. 96). Robert turns to a new legend, and vampires are scared of humans in the same way that we used to be scared of them. The text symbolically divides the thinking creatures all over the world into two confronting groups; humans versus vampires. By doing this, the novel refers to the hostility between two groups who are involved in a war. Actually, everything starts and ends with a war. In a flashback, when Robert is talking to Kathy his wife, he claims that "'half the people on the block have it [the disease], and you say that more than half the plant is absent" by which he means "some kind of virus". She shook her head saying "I don't know" (Matheson, 1997, p. 28). The storms created by the war have grounded the increase of mosquitoes which transfer the bacteria; and the spread of these insects shows the destructive consequences of war as Robert says "we are entering the age of the insect" (Matheson, 1997, p. 28). This symbolizes the fact that the communities which fight a war against each other get closer to primitive ways of life (and communication). Later on, Robert and his wife acknowledge that in a war neither party can be the winner: 
"“they say we won the war," she said.

"Nobody won it" "The mosquitoes won it."

"He smiled a little. "I guess they did," he said"” (Matheson, 1997, p. 29).

Actually no one can win a war because war is the ground of the annihilation of the human races.

Robert's encounter with Ruth is also significant. When he sees her the first time, she is walking under the sun while she is tanned. But under the sun, the vampires can't come out. Robert becomes pretty much assured that Ruth is human. So, he chases her because he believes that his wish has come true. He is not alone anymore, for he captures her. But the moment she shows reaction to garlic and her body smells like vampires he starts to suspect that she is a vampire. It is significant that as soon as he suspects of her humanity he starts showing hostility to her while she is still calm. Robert wants to make sure that she is really not human. If she is not human, he will no longer welcome her with pleasure. Although Ruth is on a mission to extract information from Robert, she wants something more than that. Sometimes she shows warm attitudes towards her. Later on, she even warns him in a note to leave the city and go to the mountains to protect his life. But she disagrees with his execution. However, when she perceives the point that Robert wants to distort the dialogue because she is not like him, she also gives herself up caring for dialogue. This point becomes additionally obvious when she doesn't want him to test his blood, because she thinks that it does not matter and she wants him to accept her the way she is. She behaves in a way that it does not matter whether or not she is a vampire, she just wants some sort of communication. But Robert does not want to have such a kind of dialogue. At the end, both vampires and Robert Neville choose the monologic ending which leads to the extinction of human race; one side is finally destroyed.

\section{Conclusion}

In a monopolizing (authoritative) system, "everything ideological falls into two categories; the first category is certain thoughts-true, signifying thoughts" (Bakhtin, 1984, p. 79), and the second category is comprised of those thoughts which are not considered false or untruthful by the authority. Truthful thoughts "gravitate toward the author's consciousness, and strive to shape themselves in the purely semantic unity of a worldview; such a thought is not represented, it is affirmed" (Bakhtin, 1984, pp. 79-80). When a community is fractured into (two) parties, if the parties can enjoy the advantages of no dialogic negotiation, it is much likely that a hostile confrontation takes place between them while the dominant party tries to destroy the minor one. Matheson's novel is a representation of the confrontation in such a radical situation of such two fractures which cannot enjoy the advantages of dialogism. In the scenario illustrated by the novel, even the relations between the protagonist and his wife and neighbors are considered as false, because these guys go under metamorphosis and turn to creatures that show liking to kill Robert. In addition, their metamorphosis shows that the dialogue among them is distorted in a radical situation when their society is on a very significant turn. The last survivor of the human race should live upon the leftovers of the previous civilization because that civilization has tried to "shut down the dialogue." The consequences of this venture of dialogue annihilation are much more than just loneliness, because in this way a new race comes into existence who are not humans but vampires. Between these humans and vampires no dialogue is likely to be made. In such a dramatic setting, the last survivor of the human race shall be executed by the vampires who are themselves the products of the war the humans have fought against each other. War is inevitable, because some human creatures abandon the dialogic and try to impose their own monologues upon other human creatures. Consequently, Robert Neville, the last human creature, becomes the victim of the monologic, while it seems that his final execution symbolizes the shattering of the last illusions of dialogue in the modern man.

\section{References}

Bakhtin, M. M. (1984). Problems of Dostoevsky's Poetics (C. Emerson, Trans. Vol. 8). University of Minnesota Press. Bakhtin, M. M. (1981).The Dialogic Imagination: Four Essays. (C. Emerson and M. Holquist, Trans.). University of Texas Press.

Bemong, Nele and Pieter Borghart. (2010). "Bakhtin's Theory of the Literary Chronotope: Reflections, Applications, Perspectives." in Bemong Nele et al. (Eds.). Bakhtin's Theory of the Literary Chronotope: Reflections, Applications, Perspectives. Gent: Academia Press. pp. 1- 16.

Dentith, S. (1995). Bakhtinian Thought: An Introductory Reader. London: Routledge Publications.

Freedman, S.W. and A. Ball. (2004). "Ideological Becoming: Bakhtinian Concepts to Guide the Study of Language, Literacy, and Learning.” in Ball, A., \& S. W. Freedman. (Eds.) Bakhtinian Perspectives on Language, Literacy and Learning. Cambridge University Press. pp. 1-33.

Holquist, M. (2002). Dialogism: Bakhtin and His World. London: Psychology Press.

Kershner, R. B. (2001). "Mikhail Bakhtin and Bakhtinian Criticism.” In Julian Wolfreys. (Ed.). Introducing Literary Theories: A Guide and Glossary. Edinburg University Press. pp. 19-32.

Matheson, Richard. (1997). I am Legend. Kindle version. PDF.

Vaagan, R. W. (2007). “Open Access Scientific, Electronic Publishing and Bakhtinian Dialogism.” Westminster Papers in Communication and Culture, 4(2), pp. 85-99.

White, E.J. (2008). Bakhtinian Dialogism: A Philosophical and Methodological Route to Dialogue and Difference? New Zealand: Victoria University of Wellington Press. 